\title{
WHEN WERE THE WALLS OF JERUSALEM LAST GLACIATED?
}

\author{
by D.G. Hannan and E.A. Colhoun \\ (with two text-figures)
}

HANNAN, D.G. \& COLHOUN, E.A., 1991 (20:xii): When were the Walls of Jerusalem last glaciated? Pap. Proc. R. Soc. Tasm. 125: 16. https://doi.org/10.26749/rstpp.125.1 ISSN 0080-4703. School ofEducation, University of Tasmania at Launceston, Box 1214, Launceston, Tasmania, Australia 7250 (DGH); Department of Geography, University of Newcastle, Rankin Drive, Newcastle, NSW, Australia 2308 (EAC).

There is evidence to indicate that parts of the Walls of Jerusalem National Park have been glaciated on two occasions. No evidence of ea rlier glaciations has been found, although at least two older periods of glaciation have been demonstrated in adjacent areas.

During the last glaciation, the Rowallan Glaciation, there was an incomplete ice cover and a large ice window, centred on the West WallSolomons Jewels area, extended from Mt Jerusalem to Howells Bluff. Rowallan-age end moraines trace the limits of this glaciation and the main erosional effects are extensive knock and lochan landscapes. The previous glaciation, the Arm Glaciation, probably covered the entire region except for the higher parts of the West Wall.

The Rowallan Glaciation reached its maximum in the Mersey Valley before $13400 \pm 600$ years BP. Deglaciation of the upper Mersey Valley was complete before $9760 \pm 720$ years BP. The Arm Glaciation is likely to be older than 130000 years.

Key Words: Walls of Jerusalem National Park, World Heritage, glaciation, Tasmania.

\section{INTRODUCTION}

The Walls of Jerusalem area was proclaimed a national park in 1981 and, with a large adjoining area, known as the Tasmanian Wilderness World Heritage Area, was nominated for World Heritage status in 1989. The Walls of Jerusalem National Park incorporates an area of 11510 ha on the western margin of the Central Plateau (fig. 1). The boundaries to the north and south respectively are Deception Point and Pine River. Lake Ball and the plateau edge through Clumner Bluff and Howells Bluff form the western boundary, and an irregular eastern boundary exists some $5 \mathrm{~km}$ east of Mount Jerusalem (fig. 1). The Walls of Jerusalem are formed by high, near-vertical scarps of Jurassic dolerite. They include the West Wall south of Lake Salome, the East Wall below Mount Jerusalem and the Wailing Wall on the western edge of Jaffa Vale. The area is drained by the Fish River in the north, flowing into Lake Rowallan, and the Pine River in the south, flowing into the Derwent River catchment. Numerous lakes, particularly in the east, have caused the area to be called "The Land of Ten Thousand Lakes" (Jennings \& Ahmad 1957). The highest peaks of the region are King Davids Peak $(1470 \mathrm{~m})$, Mt Jerusalem (1469 m) and Clumner Bluff (1458 $\mathrm{m})$.

The bedrock is almost entirely Jurassic dolerite. The exceptions are a small sandstone and mudstone inlier of the Upper Parmeener Supergroup on the Temple (Forsyth 1989: 325) and possibly also in the lower part of the Fish River (Macleod et al. 1961). The dolerite has prominent vertical joints, one set of which strikes between $40^{\circ}$ and $60^{\circ}$, the other between $115^{\circ}$ and $125^{\circ}$. These joints are prominent both on air photographs and on the ground, due to intensive exploitation by glacial erosion. The superficial deposits are mainly glacial and periglacial sediments, which will be discussed later.

This paper is based on a regional survey conducted over the upper Mersey Valley and the adjacent part of the Central Plateau to the east. It aims to explain the glacial history of the western part of the Walls of Jerusalem National Park and, in so doing, answer the question posed in the title.

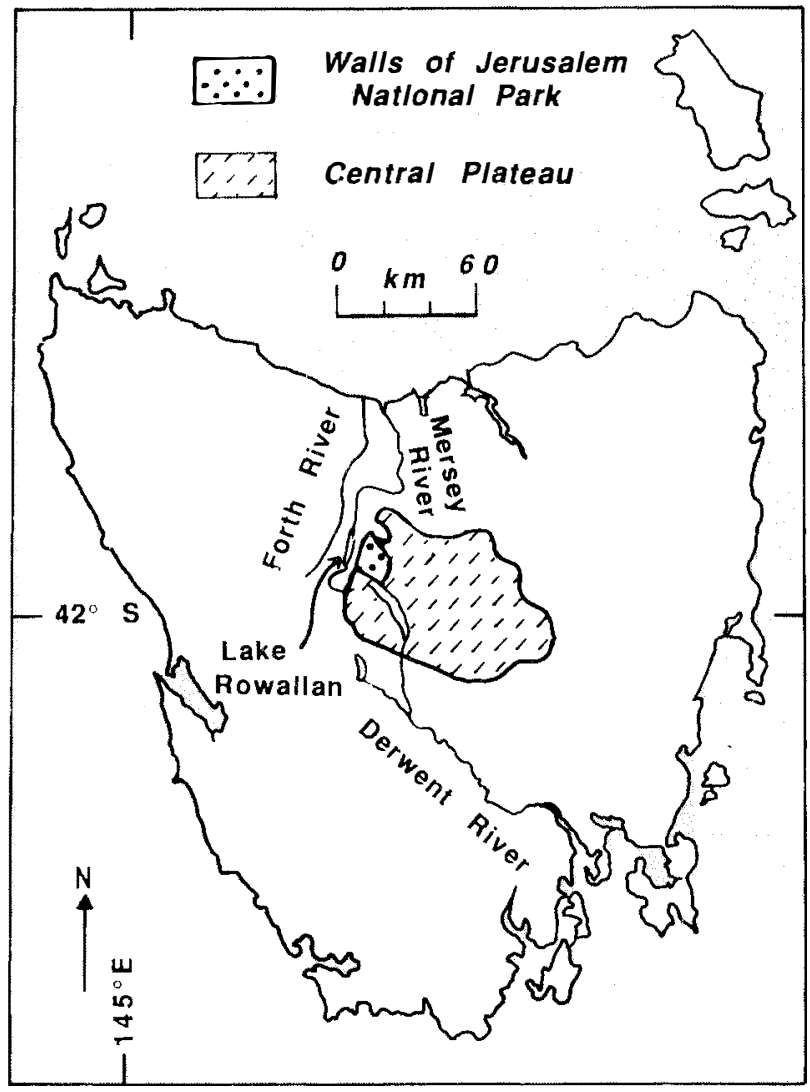

FIG. 1-General location of the Walls of Jerusalem National Park and localities outside study area which are mentioned in the text. 


\section{PREVIOUS RESEARCH}

Evidence of Pleistocene glaciation was first recognised in Tasmania by Selwyn \& Gould in 1860 (Banks et al. 1987: 232). Recognition of glacial action in the Central Plateau carne much later when Johnston (1893: 92) noted that the Central Plateau could contain an icecap capable of supplying "its western alpine valleys with numerous ice streams or glaciers". This was a complete change of mind from five years earlier, when he confidently stated that there was no evidence of post-Tertiary glaciation in Tasmania (Johnston 1888 : 256). Nye (1921: 18) rejected the evidence for Pleistocene glaciation on the Central Plateau whilst acknowledging that evidence was frequently visible on the West Coast. Lewis (1932: 15) strongly advocated that the major lakes of the Central Plateau were formed by plateau glaciation and also suggested (1932: 32) that the icecap was sufficiently large to inundate the Mersey and Forth valleys.

Jennings \& Ahmad (1957), in describing the glaciation of the westetn part of the Central Plateau, recognised only one glacial event. Other significant contributions of this paper were the identification of a major ice divide east of $\mathrm{Mt}$ Jerusalem and the delineation of erosional and depositional zones on the plateau. Geological mapping by Spry (1958), Ford (1960), Macleod et al. (1961) and Jennings (1963) all acknowledged the presence of an icecap on the plateau during the Pleistocene, which would have overflowed into the Mersey and Forth valleys. Derbyshire et al. (1965) rationalised the glacial history of Tasmania, restricted the ice-covered area and reduced the number of proven glacial events to one. Later Paterson (1965, 1969), Derbyshire (1971, 1972) and Derbyshire \& Peterson (1971) emphasised the importance of sediments in the reconstruction of the glacial history of the Central Plateau region. They also presented stratigraphic evidence for more than one glacial event in the Mersey and Forth valleys.

Using the variable thicknesses of weathering rinds on dolerite clasts in till, Kiernan (1983) suggested three stages of glaciation in western Tasmania and extended them to include the Mersey and Forth valleys. Hannan \& Colhoun (1987) provided stratigraphic evidence for the existence of three periods of glaciation in the upper Mersey Valley. They named the three glaciations from youngest to oldest as Rowallan, Arm and Croesus, providing for each a description of a basal till type section and an approximate age. Hannan (1989) presented statistical evidence for four periods of glaciation in the Mersey Valley but could not support it with stratigraphic evidence. Recently Kiernan \& Hannan (1991) have provided stratigraphic evidence for four major ice advances in the Forth Valley.

Previous work suggests that there is evidence that the Walls of Jerusalem area should have experienced the effects of ice during three and possibly four periods of glaciation. It has also been hypothesised that in at least one of these periods a major ice divide existed immediately east of $\mathrm{Mt}$ Jerusalem. It is necessary to test such a probability by examining the field evidence for multiple glaciation of the area using the features of both glacial erosion and of deposition.

\section{OVERVIEW OF THE GLACIAL HISTORY OF THE WALLS OF JERUSALEM NATIONAL PARK}

In the Walls of Jerusalem National Park there is abundant evidence for previous glaciation. Both erosional zones and depositional zones of the last two glacial episodes are to be found within the park. The intensely jointed dolerite bedrock has been stripped of soil and weathered material leaving extensive areas of knock and lochan landscape (Sugden \& John 1976: 194). In such areas there is little vegetation present. The depositional zones, by contrast, have a covering of light brown to red-brown soil developed on glacial deposits, which is capable of supporting a variety of vegetation communities, including a ground cover of grass.

Erosional landforms of the Rowallan Glaciation occur very widely within the ice limits shown on figure 2 . The dolerite surfaces are relatively unweathered and have little or no soil cover. The landforms include roches moutonnées, whalebacks, ice-eroded basins, glaciated valleys, striations, overridden plateau edges and cirques. The area to the north and west of Zion Vale is a classic knock and lochan landscape. During the Rowallan Glaciation the highest peaks of the area were nunataks, e.g. Mt Jerusalem, Clumner Bluff and King Davids Peak.

However, the erosional landforms resulting from the Arm Glaciation are more weathered, and dolerite surfaces, though generally ice moulded, exhibit solution pans up to $600 \mathrm{~mm}$ in diameter. In contrast, solution pans are absent from erosional landforms of Rowallan age. The greatest area of Arm Glaciation erosional landforms occurs in the area known as Solomons Jewels and includes ice-eroded basins, roches moutonnées and whalebacks.

Basal till of the Rowallan Glaciation can be traced from the type section at Lake Rowallan to the Walls of Jerusalem area, where it has similar characteristics to that described by Hannan \& Colhoun (1987) and Hannan (1989). The till is coherent, with almost equal proportions of matrix and clasts. The clasts are almost entirely dolerite and range in size from the smallest pebbles to boulders $2 \mathrm{~m}$ across. The colour of the till matrix is most commonly light brownish grey (7.5YR 7/1) or dull yellow-brown (10YR 5/3) (Oyama \& Takehara 1967). A fissility can be observed at many locations, which suggests deposition as basal till. Hannan (1989: 58) showed that dolerite clasts in Rowallan tills have mean rind thicknesses of less than $1 \mathrm{~mm}$ (based on 50 clasts taken randomly from an outcrop). This is consistent with the field evidence from this study and has been a useful characteristic in the Walls of Jerusalem area for distinguishing Rowallan Till from more deeply weathered Arm deposits.

Glacial depositional landforms in the Walls of Jerusalem area are confined to terminal, lateral and ablation moraines. Moraines of Rowallan age are still intact and frequently have small lakes ponded behind them. For example, there is a series of end moraines in the valley between Mt Ophel and Zion Hill which have formed small moraine-dammed lakes, the largest of which is the Pool of Siloam. In places the moraine-dammed lakes have been filled with sediment, as is the case in the upper reaches of Wild Dog Creek. Depositional features from the Arm Glaciation are more dissected, such as the moraines in the vicinity of Lake Loane.

The presence of extensive block fields and very coarse thick scree deposits was taken as indicating areas ice-free during the Rowallan Glaciation as such features are most 

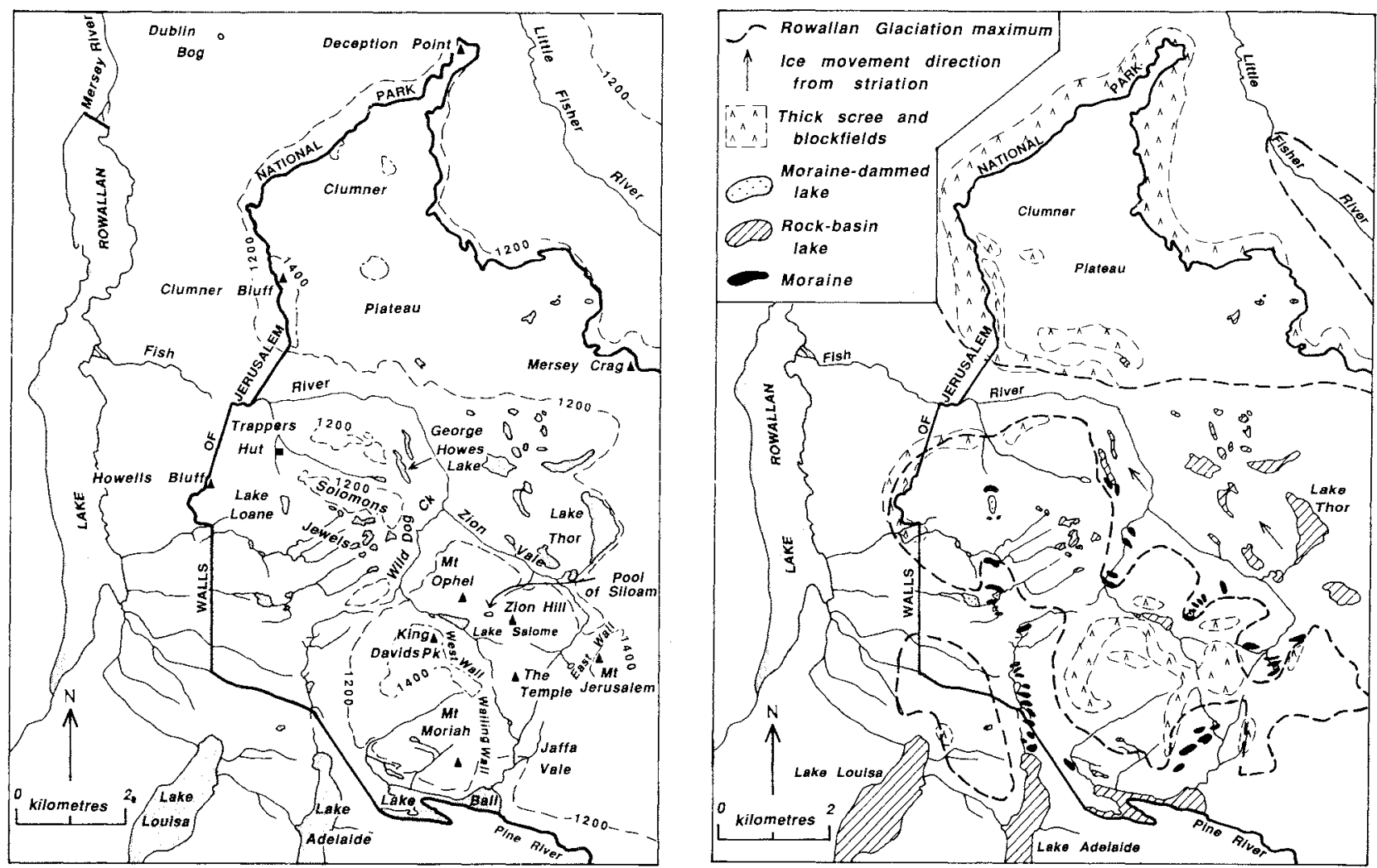

FIG. 2 - (A) Geographical localities, and (B) glacial landforms, sedimentary deposits and the Rowallan Glaciation limits for the western part of the Walls of Jerusalem National Park.

unlikely to have been developed during the brief deglaciation period of the Rowallan Glaciation. For example, the large areas of block field and scree indicate that no Rowallan Glaciation ice was present on the plateau behind Clumner Bluff. Similarly, massive scree slopes beneath the West Wall, and parts of the East Wall and the Wailing Wall, indicate that these areas were also ice-free during the Rowallan Glaciation. Figure 2 summarises the glacial features in the area.

\section{AREAS GLACIATED DURING THE ROWALLAN GLACIATION}

\section{The Lake Adelaide Ice Lobe}

Lake Adelaide (1055 m a.s.l.) and Lake Louisa ( $847 \mathrm{~m}$ a.s.l.) occupy two parallel depressions on the western edge of the Central Plateau and are separated by a dissected ridge with crests rising to approximately $1100 \mathrm{~m}$ a.s.l. Although neither of these lakes is in the Walls of Jerusalem National Park, they had great significance for the region during the Rowallan Glaciation.

The drainage in the area is deranged. Streams flow into Lake Adelaide from the east, west and north. About $20 \mathrm{~m}$ above and less than $1 \mathrm{~km}$ north of Lake Adelaide a stream in a well-developed valley flows southward out of a small lake and turns sharply west towards Lake Rowallan (fig. 2). A single stream flows from Lake Adelaide in a westerly direction into Lake Louisa.

The absence of till around Lake Louisa and the presence of scree slopes at its northern end suggest only a thin ice cover during the Rowallan Glaciation. This is further supported by extensive meltwater activity west of the lake.

By contrast, outcrops of the Rowallan Till are numerous around Lake Adelaide. They are found in the low bank on the northern foreshore of the lake, in creeks to the north of the lake and around the eastern edge of the lake. Hummocky end moraines exist up to $4.5 \mathrm{~km}$ north of the lake (frg. 2B). These end moraines provide evidence that Rowallan ice occupied the flat plain north of Lake Adelaide. The ice was not very thick because extensive screes occur to the east, down to an altitude of $1200 \mathrm{~m}$ on the slopes of the West Wall plateau. This suggests that $100 \mathrm{~m}$ south of the end moraine the maximum ice thickness would have been only $150 \mathrm{~m}$.

At the Rowallan Glaciation ice limit it is likely that ice spilled into the Mersey Valley north of Lake Adelaide. A moraine complex $800 \mathrm{~m}$ north of the lake indicates that, for a prolonged period during the Rowallan Glaciation, ice was restricted to within $1 \mathrm{~km}$ of the lake. Extensive meltwater streams have carved deep valleys in a westerly direction off the plateau. Ice spillover from Lake Adelaide to Lake Louisa would also have occurred, mainly through a steep-sided channel at the northern end of the lake.

\section{The Lake Ball-Jaffa Vale area}

During the Rowallan Glaciation, ice occupied the present site of Lake Ball and at its maximum reached a height of approximately $1300 \mathrm{~m}$ on the slopes of Mount Moriah. The surface of the ice was continuous from Lake Ball to the Lake Adelaide depression. Moraines are visible in Jaffa Vale, where diffluent ice pushed up the valley. Extensive scree slopes on the northern part of the Wailing Wall and the southern slope 
of the Temple show that the ice did not flow through the pass into the valley of Lake Salome at this time. The moraines which are visible in Jaffa Vale have a distinct northeasterly trend which coincides with the strike of prominent regional joints. It is likely that, since the ice in Jaffa Vale was stagnant, the moraines cover an ice-eroded landscape that has survived since the Arm Glaciation.

A stream flowing into Lake Ball has a barbed pattern due to glacial derangement (fig. 2).

\section{Mt Jerusalem-Zion Vale-Fish River Area}

There were two main zones of ice accumulation in the Walls of Jerusalem area during the Rowallan Glaciation. The first was the Central Plateau icecap, having its greatest thickness east of a line connecting Mersey Crag and Mount Jerusalem. Jennings \& Ahmad (1957) and Derbyshire (1968) described a major ice divide occurring east of Mount Jerusalem. On the eastern side of the divide, the main volume of ice moved generally in a southeasterly direction. Northwest of this divide, small amounts of ice flowed towards the Mersey system, via Zion Vale, and to the valley of the Little Fisher River, north of the area discussed here. The second area of accumulation centred around two cirque-like landforms. One is occupied by Lake Thor and the other occurs approximately $1 \mathrm{~km}$ north in the headwaters of the Fish River. Ice from this second source area flowed into the main Mersey glacier via the Fish River valley.

The Central Plateau icecap has left abundant evidence of its presence east of Mount Jerusalem. An extensive sloping plain of smoothed, bare rock is present, with roches moutonnées indicating ice movement to the southeast. Little soil or vegetation exists and numerous depressions, many filled by lakes, ponds and marshes, are dotted across the landscape. On the northern slopes of Mount Jerusalem, the bare rock is striated in places and gives indication that ice also moved northwest and west from the main icecap. Screes beneath the East Wall are lower and thicker towards the south than in the north, where they were trimmed by ice flowing from the Central Plateau. End moraines and a moraine-dammed lake are present beneath the southern end of the East Wall.

A relatively small volume of ice, considering the size of the icecap, flowed past the northern end of Mount Jerusalem. Of this, only a small proportion spilled into Zion Vale. The main volume moved northwestwards, as indicated by striations and the orientation of roches moutonnées (fig. 2), through Lake Thor and the "cirque" at the head of the Fish River. The ice in Zion Vale produced three small lobes which projected into the core of the National Park. It achicved a maximum thickness of $110 \mathrm{~m}$, as it barely overtopped the low divide into the valley of Lake Salome, leaving behind a series of end moraines and moraine-dammed lakes, including the Pool of Siloam. Downstream, ice flowed into the valley of the Fish River, rising to George Howes Lake. A small diffluent ice lobe extended up Wild Dog Creek. Little, if any, ice of Rowallan age flowed northwards onto the Clumner Plateau. The ice margin reached a height of approximately $1250 \mathrm{~m}$ before it was diverted westwards into the Fish Valley. A substantial meltwater channel flowed through the unnamed creek which enters the Fish Valley close to Trappers Hut. In the creekbed below Trappers Hut on the southern flank of the Fish Valley, till is found up to $950 \mathrm{~m}$ and scree slopes are trimmed off just above this level, at 980-1000 m. On the northern side of the river, the highest till outcrop is close to $1100 \mathrm{~m}$, in the creek which flows from Clumner Plateau. On the Walls of Jerusalem walking track below Trappers Hut, there are many glacial features visible, such as lateral moraines (e.g, at $860 \mathrm{~m}$ and $980 \mathrm{~m}$ ), meltwater channels (e.g. at $860 \mathrm{~m}$ ) and kame terraces (e.g. at $950 \mathrm{~m}$ ).

The Little Fisher River flows from the Central Plateau north of the Walls of Jerusalem National Park. Rowallan age ice spilled over from the central icecap and flowed about $5 \mathrm{~km}$ down the valley to the moraines which are evidence for the Little Fisher ice lobe. Ford (1960) mapped an area of "terminal moraines" in a similar locality. The moraines form low undulations in the landscape and cannot be traced for more than $30-40 \mathrm{~m}$ across the valley.

\section{AREAS UNGLACIATED DURING THE ROWALLAN GLACIATION}

\section{The Clumner Plateau}

The abundant scree deposits containing numerous large blocks of dolerite suggest that ice of the Rowallan Glaciation was absent from this plateau. It is very likely that ice of the Arm Glaciation penetrated the region, in particular into the broad valley behind Clumner Bluff which has a distinct U-shape, possibly the result of deepening by ice action.

Below the scarp of Clumner Bluff there are some very large blocks of dolerite suggesting that slabs of dolerite toppled from the main face. It is likely that the dolerite in this locality was removed from the scarp by slab failure, where a jointed dolerite column develops shears at the base and catastrophic failure occurs, causing the block to fall (Caine 1983: 138).

\section{The East Wall-West Wall Area}

The Temple, East Wall, West Wall, Mount Ophel, Zion Hill, Mount Moriah and Lake Salome were all ice-free during the Rowallan Glaciation. Evidence of this is provided by significant block stream development to the east of the col between the Temple and Zion Hill, which would have been the main avenue for ice from the Central Plateau into the area. Extensive screes occur at the base of the West Wall and East Wall. These thick coarse screes in the core of the Walls of Jerusalem National Park contrast with the relative dearth of scree within the limits of Rowallan age ice. The contrast suggests that the thick screes were developed over a long time and are unlikely to have been formed since the decay of the Rowallan ice. The valleys between these screes contain soils on thick deposits possibly derived from solifluction material. Around Lake Salome for instance there is up to $2 \mathrm{~m}$ of brown clay-rich material underlying poorly formed dark alpine humus soil. Such soil formation is not found in areas known to have been glaciated by Rowallan age ice.

Parallel ridges resembling moraines and striking towards Lake Salome from the pass between the Temple and the West Wall could be moraine remnants from the Arm Glaciation. Arm ice would probably have covered all of this area, with the possible exception of the higher parts of the West Wall. 


\section{Solomons Jewels-Howells Bluff Area}

The Solomons Jewels area has an abundance of clearly defined glacial erosion features such as basin lakes, roches moutonnées and whalebacks. There are also a large number of dolerite ice-transported boulders and infrequent till outcrops. It is inferred that these are the result of the Arm Glaciation since some outcrops of till are weathered and the contained dolerite clasts have weathering rinds in excess of $1 \mathrm{~mm}$. The presence of solution pans on the erosional landforms is also indicative of a long period of chemical weathering since ice erosion of the initial surface.

\section{AGES OF THE GLACIATIONS}

The minimum age of the Rowallan Glaciation in the Mersey Valley has been established from a ${ }^{14} \mathrm{C}$ date on charcoal at the base of a core taken from lake sediments behind the end moraine at Dublin Bog. The age is $13400 \pm 600 \mathrm{BP}$ (SUA 2188) (Hannan \& Colhoun 1987: 44). A basal ${ }^{14} \mathrm{C}$ date from cultural deposits in the upper Mersey Valley (Lourandos 1983: 39) of 9760 \pm 720 (Beta 4757) indicates that the upper Mersey Valley was deglaciated by this time. Further evidence for the minimum age of deglaciation in the Walls of Jerusalem area comes from a ${ }^{14} \mathrm{C}$ date taken at a depth of $2 \mathrm{~m}$, from a raised Sphagnum bog in Zion Vale below Mt Jerusalem. This produced an age of $8270 \pm 270$ years BP (ANU-5794) (Whinam et al. 1989:14). There is no local evidence which defines the onset of glaciation but in other parts of the state this has been estimated as 25000 years BP (Colhoun \& van de Geer 1986)

The Arm Glaciation is beyond the range of radiocarbon dating. Hannan \& Colhoun (1987: 44) and Hannan (1989: 131) estimate an age in excess of 100000 years based on relative weathering criteria from analysis of dolerite weathering rinds. Such an estimate indicates that the Arm Glaciation is likely to have preceded the last interglacial and therefore the deposits are probably more than 130000 years in age.

\section{CONCLUSION}

The Walls of Jerusalem National Park contains abundant evidence of glaciation. The erosional landforms produced by the last period of glaciation, the Rowallan Glaciation, are relatively unweathered. As a result they are often observed cut in to bare rock with little soil development or vegetation around them. Depositional landforms are little eroded and the end moraines have been used to plot the limits of the glaciation. The till deposits are largely unweathered. The shape of the ice cover during this time was complex, with the main feature being a large ice window in the centre of the national park. A number of short ice lobes, some diffluent, penetrated towards the core of the park but did not engulf the area. A major ice divide east of $\mathrm{Mt}$ Jerusalem was responsible for most of the ice flowing off in a southeasterly direction. A small proportion of ice flowed northwestwards into the Fish Valley and the Little Fisher Valley. The ice in the Fish Valley formed a major tributary of the main Mersey glacier. The ice in the Little Fisher Valley terminated some $5 \mathrm{~km}$ from the edge of the Central Plateau.

The Arm Glaciation would appear to have covered most of the Walls of Jerusalem National Park area, with the possible exception of the higher parts of the West Wall. Parts of the region forming the ice window during the Rowallan Gaciation still exhibit erosional and depositional features formed during the Arm Glaciation.

To answer the question posed in the title it would appear that most of the Walls of Jerusalem National Park was glaciated between 25000 and 10000 years BP. The central part of the park, from the West Wall to Solomons Jewels was ice free during this time and was probably last glaciated more than 130000 years BP.

\section{ACKNOWLEDGEMENTS}

Grateful acknowledgement is given to Brian East, Mike Dunphy, Darrell Fisher and John Hannan for assistance in the field.

\section{REFERENCES}

Banks, M. R., Colholn, E. A. \& HanNan, D. G., 1987: Early discoveries of the effect of ice action in Australia. J. Glaciol. 33 (114): 231-235.

CAINE, N., 1983: THE MOUNTAINS OF NORTHEASTERN TASMANIA. Balkema, Rotterdam.

ColHoun, E.A. \& van DE Geer, G., 1986: Holocene to middle last glaciation vegetation history at Tullabardine Dam, western Tasmania. Proc, R. Soc. Lond. B227: 177-207.

Derbyshire, E.D., 1968: Glacial map of NW-central Tasmania Rec. Geol. Surv. Tasm. 6.

Derbyshire, E.D., 1971: On the status and correlation of glacial episodes in southeastern Australia. Search 2(8): 285-288.

Derbyshire, E.D., 1972: Pleistocene glaciation of Tasmania: Review and speculations. Aust. Geogr. Stud. 10: 79-94.

Derbyshire, E.D., Banks, M.R., Davies, J.L. \& Jennings, J.N., 1965: A GLACIAL MAP OF TASMANIA. Roy. Soc. Tasm. Spec. Publ. 2.

Derbyshire, E.D. \& Peterson, J.A., 1971: On the status and correlation of Pleistocene Glacial Episodes in southeastern Australia. Aust. J. Sci. 2(8): 285-288.

Ford, R.J., 1960: The geology of the Fisher River area. Pap. Proc. R. Soc. Tasm. 94: 25-34.

ForsYTh, S.M., 1989, Upper Parmeener Supergroup. In Burrett, C.F. \& Martin, E.L. (Eds): GEOLOGY AND MINERAL RESOURCES OF TASMANIA. Geol. Soc. Aust. Spec. Publ. 15.

Hannan, D. G., 1989: Glacial history of the upper Mersey Valley. Unpublished M.Sc. thesis, University of Tasmania.

Hannan, D.G. \& ColHoun, E.A., 1987: The glacial stratigraphy of the upper Mersey Valley. Aust. Geogr. Stud. 25(2): 36-46.

Jennings, I.B., 1963: Middlesex, Tasmania. Tasm. Dep. Mines 1 Mile Atlas Series, Expl. Rep. Sheet K/55-6-45.

Jennings, J.N. \& Ahmad, N., 1957: The legacy of an ice cap. Austr. Geogr. 11(2): 62-75.

JOHNSTON, R.M., 1888: A SYSTEMATIC ACCOUNT OF THE GEOLOGYOF TASMANLA. Government Printer, Hobart.

Johnston, R.M., 1893: The Glacier Epoch in Australia. Pap. Proc. R. Soc. Tasm. : 73-134.

KiERNAN, K, 1983: Weathering evidence for an additional glacial stage in Tasmania. Aust. Geogr. Stud. 21(2): 197-220.

Kifrnan, K. \& Hannan, D.G. (1991): Glaciation of the upper Forth River catchment, Tasmania. Aust. Geogr. Stud. 29(1): 155-173.

LEWIS, A.N., 1932: Note on the origin of the Great Lake and other lakes on the Central Plateau. Pap. Proc. R. Soc. Tasm.: 1538.

Lourandos, H., 1983: 10,000 years in the Tasmanian highlands. Aust. Archaeol. 16: 39-47. 
MAC IEOD, W.N., JaCK, R.H. \& Threader, V.M., 1961: Du Cane, Tasmania. Tasm. Dep. Mines 1 Mile Atlas Series, Expl. Rep. Sheet K/55-11-52.

NYE, P.B., 1921: The underground water resources of the midlands Tasmania. Underground Water Supply Bull. 1, Tasmanian Dep. Mines, Hobart.

OYANA, M. \& TAKEHARA, H., 1967: REVISED STANDARD SOIL COLOR CHARTS. Japanese Research Council for Agriculture, Forestry and Fisheries, Tokyo.

Paterson, S.J., 1965: Pleistocene drift in the Mersey and Forth Valleys - probability of two glacial stages. Pap. Proc. R. Soc. Tasm. 99: 15-124.
Paterson, S.J., 1969: Pleistocene deposits at Parangana Damsite in the Mersey Valley - results of excavation and construction drilling. Pap. Proc. R. Soc. Tasm. 103: 57-61.

SPRY, A., 1958: The Precambrian rocks of Tasmania Part 3, MerseyForth area. Pap. Proc. R. Soc. Tasm. 92: 117-142.

SUGden, D.E. \& JOHN, B.S., 1976: GLACIERS AND LANDSCAPE A GEOMORPHOLOCIAL APPROACH. Arnold, London.

Whinam, J., EBERHaRd, S., Kirkpatrick, J. \& Moscal, T., 1989: ECOLOGY AND CONSERVATION OF TASMANIAN SPHAGNUM PEATLANDS. Tasmanian Conservation Trust Inc., Hobart.

(accepted 7 December 1990) 